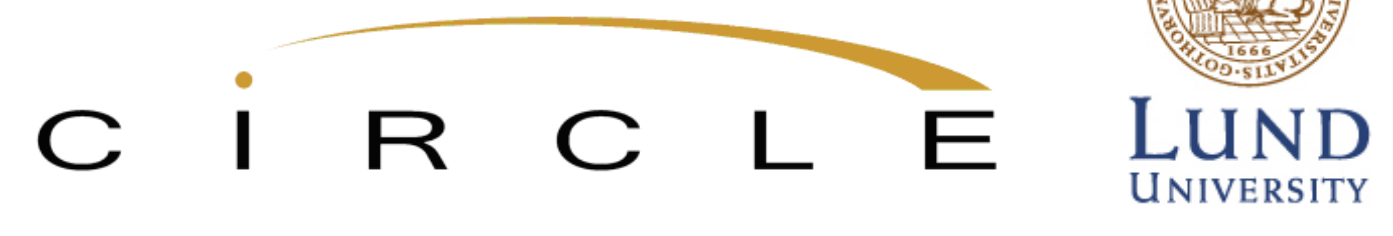

\title{
The Virtual is Reality! \\ On Physical and Virtual Space in Software Firms' Knowledge Formation
}

\author{
Heidi Wiig Aslesen (heidi.w.aslesen@bi.no) \\ BI Norwegian Business School, Norway \\ Roman Martin (roman.martin@handels.gu.se) \\ Gothenburg University, Sweden \\ Stefania Sardo (stefania.sardo@bi.no) \\ BI Norwegian Business School, Norway
}

\section{Papers in Innovation Studies \\ Paper no. 2018/09}

Centre for Innovation, Research and Competence in the Learning Economy (CIRCLE)

Lund University

P.O. Box 117, Sölvegatan 16, S-221 00 Lund, SWEDEN

http://www.circle.lu.se/publications 


\title{
The Virtual is Reality! On Physical and Virtual Space in Software Firms' Knowledge Formation
}

\author{
Heidi Wiig Aslesen, Roman Martin, Stefania Sardo
}

\begin{abstract}
To understand how knowledge is created, it is necessary to unwrap the role played by the physical and virtual spaces in knowledge exchange and formation. The extant research offers interesting findings when it comes to the relationships among regional institutional and organizational characteristics, innovation, and firms' abilities to link up to global knowledge sources. A focus on the role of informal and low-cost mechanisms, both regional and global, has extended our understanding of their role in knowledge formation. However, the physical space has dominated the discussion in the literature on sources of knowledge formation, while the virtual space has seldom been addressed. The inclusion of the virtual space, both as an interaction space and as a different and complementary dimension, makes it possible to gain new insights into knowledge formation in a digitalizing world. Based on in-depth interviews with small and medium-sized software companies in two urban agglomerations in Norway and Sweden, this paper explores the use of physical and virtual spaces. The findings show that these spaces interact and mutually influence each other. The world is not 'flattening' due to ongoing digitalization. Rather, urban agglomerations are still important places in which these spaces are optimized and unified.
\end{abstract}

Keywords: virtual space; knowledge sources; geographical proximity; software firm; Norway; Sweden

JEL: O30; O31; L86

Disclaimer: CIRCLE does not take any responsibility for opinions and views expressed by the authors in this paper. 


\title{
The Virtual is Reality! On Physical and Virtual Space in Software Firms' Knowledge Formation
}

Heidi Wiig Aslesen, BI Norwegian Business School, Nydalsveien 37, 0484 Oslo, Norway. Phone: +47 464108 41. E-mail: heidi.w.aslesen@bi.no

Roman Martin, School of Business, Economics and Law, University of Gothenburg, Sweden. Phone: +46 317864193. E-mail: roman.martin@handels.gu.se

Stefania Sardo, BI Norwegian Business School, Nydalsveien 37, 0484 Oslo, Norway. Phone: +47464108 01. E-mail: stefania.sardo@bi.no

\begin{abstract}
To understand how knowledge is created, it is necessary to unwrap the role played by the physical and virtual spaces in knowledge exchange and formation. The extant research offers interesting findings when it comes to the relationships among regional institutional and organizational characteristics, innovation, and firms' abilities to link up to global knowledge sources. A focus on the role of informal and low-cost mechanisms, both regional and global, has extended our understanding of their role in knowledge formation. However, the physical space has dominated the discussion in the literature on sources of knowledge formation, while the virtual space has seldom been addressed. The inclusion of the virtual space, both as an interaction space and as a different and complementary dimension, makes it possible to gain new insights into knowledge formation in a digitalizing world. Based on in-depth interviews with small and medium-sized software companies in two urban agglomerations in Norway and Sweden, this paper explores the use of physical and virtual spaces. The findings show that these spaces interact and mutually influence each other. The world is not 'flattening' due to ongoing digitalization. Rather, urban agglomerations are still important places in which these spaces are optimized and unified.
\end{abstract}

Keywords: virtual space, knowledge sources, geographical proximity, software firm, Norway, Sweden

JEL codes: O30, O31, L86

Acknowledgements: This work was supported by the Marianne and Markus Wallenberg Foundation under grant number 2012.0194.

\section{Introduction - The Geography of Knowledge Sources}


As a result of the ongoing digital revolution and the rapid diffusion of information and communication technologies (ICTs), economic geographers and innovation scholars have become increasingly interested in the role of virtual space in knowledge creation and innovation (Bathelt and Turi 2011). Recent studies deal with the extent to which ICT can facilitate geographically distant innovation networks (Leamer and Storper 2001; Kaufmann, Lehner, and Tödtling 2003) and convey codified and tacit knowledge (Romano, Passiante, and Valerio 2001; Vaccaro, Veloso, and Brusoni 2009). These discussions have given rise to debates regarding the supposed advantages of geographical proximity. At the same time, they have related the virtual dimension in rather static and predefined ways, and consequently failed to take the ongoing progress in ICTs and the mechanisms firms employ to create and maintain knowledge into account. For example, the virtual space is often viewed as merely a repository of codified knowledge. The physical space, in contrast, is seen as facilitating tacit knowledge exchange by enabling face-to-face (F2F) interactions and interactive learning, typically within geographical proximity (Asheim 1999; Roberts 2000; Johnson, Lorenz, and Lundvall 2002). At times, the virtual dimension is seen as promoting the formation of trust among partners, thereby paving the way for physical and more binding forms of knowledge exchange and cooperation (Tödtling, Lehner, and Trippl 2006; Grabher and Ibert 2018).

Geographical proximity is generally acknowledged as having a positive effect on interactive learning and knowledge exchange (Bathelt and Glückler 2003; Storper and Venables 2004; Morgan 2004; Yeung 2005; Asheim, Coenen, and Vang 2007a). However, researchers have recently argued that it is neither a necessary nor a sufficient condition - other forms of proximity must be present, such as cognitive, organizational, social, cultural or institutional proximity (Boschma 2005). The combination, interrelatedness and mutual reinforcement of these various types of proximity (Knoben and Oerlemans 2006), as well as the balance in the degrees of distance and proximity within each type, may create a fertile innovative environment. The overlap and potential substitution of different types of proximities helps explain how firms can exchange and construct knowledge with partners located in very different places (Menzel 2015).

An increasing number of firms in the global economy are multi-product and multi-technology firms. They innovate by leveraging on a combination of knowledge types from different sources and scales (Manniche, Moodysson, and Testa 2017; Grillitsch, Martin, and Srholec 2017). Many such firms are found in the software industry, which is a subset of the ICT sector that comprises consultancy, database activities, research and experimental development (Cooke et 
al. 2007). Given the need to maintain the pace of innovation and to gather up-to-date knowledge from various domains, these firms collaborate with heterogeneous actors (Grabher 2004; Ibert 2004; Segelod and Jordan 2004). Indeed, they cut across several knowledge bases and through different spaces (Aslesen and Freel 2012; Martin and Rypestøl 2017). The software industry tends to localize in urban agglomerations (Isaksen 2006) where firms can access a variety of industries as well as higher education and research organizations, whose proximate location increases the opportunities for frequent interaction and for the recombination of related (and unrelated) knowledge bases, leading to new innovations (Isaksen and Trippl 2016). Cities can be creative and cultural hot spots, with a 'people climate' that attracts human capital, talented individuals and creative class members (Storper and Venables 2004; Trippl 2013). Moreover, cities offer access to symbolic knowledge bases through informal interactions with endconsumers as well as local buzz, and non-commercial, civic, daily-life contextual settings (e.g., street cultures, public events; Manniche 2012). This facilitates the transfer of rumours and know-who knowledge, which are important for building personal networks (Grabher 2002; Johnson, Lorenz, and Lundvall 2002; Jensen et al. 2007).

Although the extant literature on sources of knowledge and their geographies offers important findings, researchers have tended to focus on physical space while disregarding the virtual space. By considering the virtual dimension as an interaction space that differs from the physical space, we aim to provide a better understanding of how different spaces affect knowledge formation. Therefore, the research question addressed in this paper is the following: How do software firms use physical and virtual spaces as sources of knowledge?

The paper is organized as follows. Section 2 provides a review of the literature on the geography of knowledge sourcing with a focus on physical and virtual spaces. Our data-collection process and methodology are described in Section 3, followed by the analysis and the discussion of our findings in Sections 4 and 5, respectively. Section 6 concludes the paper and proposes ideas for further research.

\section{Literature Review - Knowledge Sources in Physical and Virtual Space}

Learning and innovation processes do not take place in isolation, but result from the actions of interdependent actors who are heterogeneous with respect to their knowledge, skills and roles (Lundvall 1992; Bathelt, Malmberg, and Maskell 2004; Asheim et al. 2007b). Innovative firms supplement internal knowledge and skills with the knowledge and skills found in a number of external sources by employing various knowledge-sourcing mechanisms. The next section 
presents a literature review focused on the physical and virtual spaces in which innovationrelated knowledge is sought out and exchanged.

\subsection{Sources of Knowledge in the Physical Space - Geographical Proximity}

A widespread argument for the role of geographical proximity in knowledge creation revolves around the notion of local buzz and tacit knowledge. Tacit knowledge is an essential component of local competitive advantage, as it tends to be spatially sticky and easily exchanged via F2F interactions (Markusen 1996; Asheim and Isaksen 2002; Gertler 2003; Storper and Venables 2004; Bathelt and Turi 2011; Fai, Tomlinson, and Branston 2014). Local buzz is understood as the 'information and communication ecology created by F2F contacts, co-presence and colocation of people and firms within same industry and place or region' (Bathelt, Malmberg, and Maskell 2004, 38). It is rooted in geographical and relational proximities and involves mutual trust, a shared understanding of problems and objectives, a sense of belonging, common rules, behavioural norms and social capital (Bathelt and Glückler 2003; Ibert 2010). Labour mobility from one firm to another creates knowledge spillovers and typically (though not exclusively) takes place in geographical proximity (Trippl, Tödtling, and Lengauer 2009; Boschma, Eriksson, and Lindgren 2009). Therefore, a relationship between geographical proximity and knowledge exchange has been suggested - the former influences collaborative behaviour and cognitive proximity, as well as the types of knowledge that can be created and exchanged (Grabher 2002; Storper and Venables 2004; Owen Smith and Powell 2004; Asheim and Gertler 2005; Maskell, Bathelt, and Malmberg 2006; Asheim et al. 2007b). Within a region, a knowledge ecology is created and exploited by agents embedded in the same space. That ecology twists around a shared cognitive frame, which has a cumulative, self-reinforcing character (Grabher 2002; Storper and Venables 2004). The place itself becomes an interactionopportunity enhancer: social behaviour patterns develop because geographical proximity creates opportunities for frequent interactions and tacit knowledge exchange. At the same time, the local context triggers less systematic 'serendipitous encounters', which might lead to creative opportunities (Merton and Barber 2004; Brinks et al. 2018).

Those not belonging to this regional environment might find it difficult to absorb and use this knowledge, as they are not institutionally and culturally proximate (Boschma 2005). As such, they are not equipped with the interpretative toolbox provided by cultural norms, laws and established practices (Gertler 2003; Leamer and Storper 2001; Morrison, Rabellotti, and Zirulia 2012). As argued by Grabher and Ibert $(2014,98)$, 'physical proximity co-produces relational 
proximity, and relational proximity in turn promotes learning as it cultivates mutual understanding'. However, the argument that physical proximity promotes relational proximity and facilitates knowledge exchange does not imply that physical proximity is a sufficient or necessary precondition for knowledge exchange. Actors may be closely co-located without having a mutual understanding that would allow for a fruitful exchange of ideas. At the same time, knowledge may be transferred between geographically distant actors. Such transfers may be facilitated by relational forms of proximity.

\subsection{Sources of Knowledge in the Physical Space - Geographical Distance}

Links with extra-regional knowledge sources are essential for ensuring that agents do not become locked into a certain way of understanding the world (Grabher 1993; Boschma 2005). The level and success of extra-regional knowledge sourcing depends, in part, on the region's economic and institutional characteristics, such as public support for innovation and the absorptive capacity of local firms (Trippl, Grillitsch, and Isaksen 2017). This suggests that the regional institutional characteristics and the ability to access extra-regional sources of knowledge are interdependent.

In today's world economy, resources are increasingly distributed on a global scale (Bathelt, Malmberg, and Maskell 2004; Gertler and Levitte 2005; Malmberg and Power 2005; Maskell, Bathelt, and Malmberg 2006; Cooke et al. 2007; Hauknes and Knell 2009; Bathelt and Turi 2011; Fai, Tomlinson, Branston 2014; Fitjar and Huber 2015; Los, Timmer, and Vries 2015). Not only are technologies transferred globally, but firms can also access and co-create knowledge and collaborate in 'global innovation networks' (Cooke 2013; Ernst 2009; Malecki 2011; Parrilli, Nadvi, and Yeung 2013; Herstad, Aslesen, and Ebersberger 2014; Chaminade et al. 2017). These geographically dispersed networks are particularly important for companies in science-based industries, such as ICT (Tödtling, Lehner, and Trippl 2006), and for small open economies, such as Sweden or Norway (Powell, Koput, and Smith-Doerr 1996; Powell 1998; McKelvey, Alm, and Riccaboni 2003). They are valuable because they provide access to dissimilar goods, services, markets and ideas (Bathelt 2008; Trippl, Tödtling, and Lengauer 2009), and are often viewed as deliberately established linkages that require time and effort to build. This might lead to a reduction of the involved agents' cognitive distance (Maskell 2014) and, therefore, to an increased capacity to absorb and process external knowledge (Cohen and Levinthal 1990; Zahra and George 2002).

\subsection{Sources of Knowledge in the Physical Space - Temporary Spaces}


Buzz is not exclusively a characteristic of permanent locations. It can result from temporary physical spaces as long as agents are proximate in other ways (e.g., cognitive; Bathelt and Turi 2011). Temporary clusters can form out of conferences and international fairs when individuals belonging to the same community of practice or epistemic community exchange and create knowledge (Amin and Cohendet 2004; Grabher 2004; Maskell, Bathelt, and Malmberg 2004; Maskell 2014; Henn and Bathelt 2015; Bathelt and Gibson 2015). These spaces can be seen as 'field-configuration events' (Maskell 2014), where participants jointly define what is the relevant knowledge for their field, which are the problems and their admissible solutions, and how the technological trajectories coherently adapt. In other cases, they have the characteristics of 'field-reproducing events' in which temporary spaces lead to the reinforcement of a respective field (Henn and Bathelt 2015). Such social constructions of new meanings or reenforcements of common orientations happen through F2F interactions and group meetings, and constitute a temporary global buzz (Maskell, Bathelt, and Malmberg 2004, 2006; Bathelt and Schuldt 2008, 2010; Schuldt and Bathelt 2011; Fitjar and Huber 2015). This suggests that learning and innovation through spillovers and informal networks do not just occur among physically proximate actors with long-term relationships - they can happen in temporary spaces where geographical proximity and distance intertwine. Participants 'are both gatekeepers of knowledge and the pipelines between global buzz and local buzz' (Fai, Tomlinson, and Branston 2014, 7). These temporary events change the individuals' personal networks by adding new linkages and reinforcing existing ones. Even if some of these interactions do not prove important for innovation, they are opportunities for joint action and mutual learning.

\subsection{Sources of Knowledge in the Virtual Space}

The above sections show that knowledge linkages vary along the dimensions of geographical proximity, distance, and duration. Knowledge linkages are also generated and sustained in the virtual dimension. Some scholars explore the virtual as a dimension of space that is separate from the technological infrastructure, and that sustains both local and global linkages. Rallet and Torre (1999) study the reorganization of firms' interactions networks through the virtual space. Such networks rely on organizational proximity for the transfer and creation of tacit knowledge at distance. This allows relations to be 'shared in an organizational arrangement, either within or between organizations' (Boschma 2005, 65), and for actors to 'have the same reference space and share the same knowledge' (Torre and Gilly 2000, 174). Romano, Passiante and Valerio (2001) and Passiante and Secundo (2002) focus on the internetworked organization, which arises when digital networks create value through the integration of the supply chain and 
together compose a virtual cluster. In certain cases, these clusters are knowledge-sharing communities (i.e., virtual communities; Grabher and Ibert 2014, 2018) in which tacit and codified knowledge are created and exchanged, and the main governance mechanism is sharing (Belk 2010). The governance of such communities focuses on open innovation: communication channels are rich, property rights and incentives are viewed as antithetical, and participation is often centred on hobbies, passions or public goods (Franke and Shah 2003; Felin and Zenger 2014). Virtual buzz can be embedded in social networks that transcend specific locations, suggesting that both codified and tacit knowledge can be transferred within the virtual space. Organizational, social and cognitive proximities act as enablers without requiring permanent or even temporary physical co-location.

Taken together, these strands of the extant literature demonstrate that an increasing amount of attention is being paid to the role of the virtual space in the construction and support of knowledge sources.

\section{Method and Data - Interviews with Software Firms in Oslo and Malmö}

The aim of this paper is to improve our understanding of the role of physical and virtual spaces as sources of knowledge by examining how software firms search for and exchange knowledge. The empirical analysis is based on document studies for and in-depth interviews with representatives from firms in the software industry in the urban agglomerations of Oslo (Norway) and Malmö (Sweden). We focus on the software industry due to its high impact, growth, and rapid diffusion to all aspects of other industries and modern life. In general, the ICT and software industry provide rapidly evolving enabling technologies. At the same time, there is widespread demand for advanced solutions based on those technologies (Strambach 2012). An understanding of the spatial dynamics of the software industry is fundamental to the understanding of the modern digital economy. The sector has often been labelled as footloose and not tied to specific places, pointing to a geographically 'flattening' world economy (Friedman 2005). However, empirical evidence shows that the industry is typically concentrated in high-cost urban agglomerations, and not in peripheral regions (Isaksen 2004).

Oslo and Malmö can be seen as institutionally and organizationally thick regions (Isaksen and Trippl 2016), and they exhibit several features that explain their high level of attractiveness and absorption capacity. Both regions are major centres for software development in their respective countries (see also Isaksen 2006; Martin and Trippl 2017). In 2010, as much as 57.5 percent of Norwegian ICT employment was in the greater Oslo region, and a large part of those employees 
were working in software development (Jøranli and Herstad 2017). Malmö and the neighbouring city of Lund host some of the main players in the Swedish ICT industry, including Ericsson and Axis Communications, as well as a dynamic entrepreneurial ecosystem with a large number of small and medium-sized software developers.

In both regions, we initially contacted public support organizations to identify innovative software companies (i.e., reference-based selection; Patton 1990). The selection of software firms was steered by our desire to understand how firms search for knowledge in a context in which physical and virtual spaces are important. In total, we interviewed 24 firms ( 8 in Oslo and 16 in Malmö). The interviews were conducted between April and June 2015 in Oslo and between January and July 2016 in Malmö, and lasted between 45 and 90 minutes. The selected interviewees were key personnel (i.e., chief executive officers (CEOs) or chief technical officers (CTOs)) with comprehensive insights into the innovation and knowledge-sourcing activities of their firms. ${ }^{1}$ The sample of firms varies with respect to NACE sectors (parts of NACE 58-63 and 73-74), size (from 5 to 250 employees) and age (established between 1995 and 2012). Small and young software companies were prevalent. The interviewed firms were heterogeneous in terms of their core activities, which included the production and commercialization of own products, and the provision of technological solutions using existing semi-finished or proprietary technologies. Innovation outputs targeted different sectors (e.g., media and broadcasting, transportation, education and manufacturing), which is typical for the software industry (Martin and Rypestøl 2017). The inclusion of companies from two urban agglomerations allows us to further broaden and diversify the sample with regard to geographical context.

The interviews aimed at gathering contextual and relational data on firms' innovative behaviours. The focus was on knowledge-sourcing, knowledge-exchange and knowledgecreation activities, as well as the type and geography of knowledge linkages, especially in terms of the spaces from which they originated. The interviewees were explicitly asked to describe how and from where their companies acquired knowledge relevant for innovation.

\section{Analysis: Software Firms and their Knowledge-Sourcing Activities}

\footnotetext{
${ }^{1}$ Even though the full scope of knowledge sourcing cannot be comprehended or articulated by a single person, we are confident that the interviewed CEOs and CTOs had a good overview of their companies' most important innovation and knowledge-sourcing activities.
} 
The literature section highlighted the current debates on the roles played by the physical and virtual spaces in the search for and exchange of innovation-relevant knowledge. Despite the results of previous contributions, there is a clear gap in our understanding of how knowledge is exchanged and constructed, especially when physical and virtual spaces are combined. The following analysis explores software firms' knowledge linkages in each of these dimensions.

\subsection{Knowledge Search and Exchange in the Physical Space}

A firm's external knowledge network relies heavily on its employees' personal skills and connections. Along these lines, software firms recruit new employees for at least two reasons: 1) to obtain technical skills that match the firm's innovation strategies, and that broaden and deepen its knowledge base, and 2) to get the 'know-who' needed to widen the firm's network. This is in line with findings on the learning and innovation mechanisms used by knowledgeintensive business services (Tether and Tajar 2008). One respondent notes: 'Access is a better word. We get it from our employees, who hold the knowledge. We have it in our relationships [with] universities (...) and with partners, who also have knowledge in different areas'. The interviewed CEOs and CTOs were aware of the importance of hiring and retaining employees: 'As much as possible, we hire to keep skills and experience in-house in the long term. It is very cheap to hire people for a short period of time, but (...) we are here for the long term, so we should build the skill set and focus on hiring people that want to be here.' Much of the knowledge needed for innovation is embodied in people, and is acquired by recruiting new employees or training existing staff (Leamer and Storper 2001). The presence of technologically related firms in the region and the mobility of workers among them can cause knowledge spillovers, and contribute to the creation and sustainment of local buzz. One of the Oslo firms admits to having very high staff turnover and to frequently losing employees to local competitors: 'Luckily, some of them come back after a few years.' Most companies describe inter-firm mobility as high, which can be explained by the large number of potential employers for software developers in the two case regions. Obviously, firms benefit from co-location with other firms belonging to the same 'skilled trade', which points to the advantages that arise from localization economies (Beaudry and Schiffauerova 2009).

Even though the labour markets in Oslo and Malmö are important spaces for recruitment, a firm from Oslo reports that it has 'to hire from abroad. It is very hard to find people in Norway who are active in engineering or design.' In contrast, the software firms in Malmö report that they mostly hire within Sweden, especially from the Malmö region, with the exception of a few large companies that can afford to recruit internationally. International recruitment typically relates 
to specific programming skills, which raises the bargaining power of international candidates, who often require high salaries in order to move. International recruitment is rare and typically occurs through personal networks, in connection with temporary physical spaces (e.g., at conferences, fairs and exhibitions) or through searches in the virtual space (e.g., via online recruitment platforms). International recruitment is relevant when there is a local shortage of specialized software skills, but it is difficult to achieve for small firms that lack the financial resources and international reputation needed to attract foreign experts.

The interviews reveal that software companies rely heavily on personal networks. One respondent states: 'I think I would never have chosen to be in Norway if it was not for the people whom I randomly found to work with here. We have been in business together for twenty years'. The geographical reach of an individual's personal network depends on individual experiences and openness to the outside world: 'We travel a lot to competitors all around the world to learn from them. (...) We have informal and formal contacts, and knowledge exchange. This is used a lot.'

Personal networks of key individuals can also contribute to the success of the local industry in general. In recalling his own relationship with several business networks, one company representative states: 'That was a collective Nordic effort to go global, and the Oslo Business Region identified it as something they wanted to support (...). By serving as (...) an international ambassador for them, I have been able to provide a lot of value to Oslo. I have also been able to get plenty of value out of it by establishing activities that we needed as a company.'

Many of the interviewees view Oslo as one of the few Norwegian cities capable of guaranteeing the necessary range of services and infrastructure for innovation and informal knowledge exchange, even among competing firms. Such knowledge exchange occurs through events and training. As one interviewee states: 'There are loads of different events [in Oslo] and some good hotspots like MESH, Innovation Lab, Startuplab and INMA. They have regular events (...). We have also international concepts (...), like Pecha Kucha Night, (...) here in Oslo, which is very cool.' Similarly, the companies in Malmö appreciate the presence of other software firms and the strong public support infrastructure: 'It is a joint goal for Media Evolution, us and many other companies in the region to make Malmö the place to go to when it comes to what we are working with here. I think we have come a long way toward doing that. We have a very strong start-up scene. We have The Conference. We have Media Evolution as a cluster. We have a few really good agencies. We have a lot of angel investors. There are a lot of things going on around digital transformation and communication in this region.' 
Many of the organizations with which the interviewees collaborate have an international reach. Frequently mentioned collaboration partners in Oslo are the University of Oslo, multinational companies and banks. In Malmö, important partners include the two regional universities, the local branch of the Swedish multinational company Ericsson and local offices of various foreign multinational companies. This can be seen as another advantage of urban agglomerations: they often host multinational organizations that smaller firms can use as local hubs for global knowledge sources. As one respondent says: 'We collaborate with Cisco Systems (...). In that case, we do not need to go to California to get access to the best people in video conferencing systems.' This particular regional context helps connect people to the global scene to the extent that it is able to attract global actors as well as create linkages to relevant knowledge hubs abroad.

With regard to the role of global knowledge sources, one respondent says: 'I think it is important to be inspired. One has to go outside a rather uninspiring environment - you go where the action is.' In this regard, temporary physical spaces, such as international fairs and conferences, are valued opportunities for F2F encounters with heterogeneous actors with related interests and goals. These actors can include end users, competitors, partners, clients, research organizations and universities. Such encounters offer opportunities to exchange opinions and information, as well as to confront ideas, enforce reputations and recruit personnel with certain skills. Participants learn about the current state of technological development and, together, they shape the future of the industry. As a respondent from Oslo states: 'In our industry, things change quickly. We need to be on the cutting edge (...). You can only do that if you are out there and know what is going on (...). Therefore, [going to conferences] is absolutely necessary.' Similarly, a respondent from Malmö highlights the importance of physical presence at international conferences: 'We go to conferences. It is a good way to get inspiration (...) and international input. We have sent people to New York, Amsterdam and Norway, and here to The Conference in Malmö". At conferences, F2F meetings often lay the foundation for future collaboration. As stated by an interviewee from Oslo, 'business also emerges from meetups. You talk to someone and they need, for example, a designer for a project. We sit down, have a meeting and figure it out. Maybe we can do more than just design - we can do some other things as well'.

\subsection{Knowledge Search and Exchange in the Virtual Space}

The virtual space is the central focus attention among all interviewed firms due to its multiple functionalities as a source for codified and tacit knowledge. Different online communities were 
indicated as virtual spaces in which software developers get in touch with each other. Social media platforms (e.g., Twitter, Facebook and LinkedIn), user groups and internet fora are important virtual spaces in which people search for skills and ideas, give advice, and co-develop technologies. This is in line with Sotarauta et al. (2011), who find that software firms (belonging to the category of 'digibusiness') rate informal ties in online communities as important for gathering knowledge not tied to physical proximity.

The search for knowledge in the virtual space is facilitated by the ease of digital communication, which does not require people to be connected simultaneously or in real time, as conversations can be sequential and delayed (except for calls and virtual meetings). Furthermore, knowledge linkages in the virtual space are not necessarily bidirectional, as is usually the case with F2F interactions in the physical space, but may well be unidirectional. Following firms or individuals on online platforms may not have the intensity and reciprocity of physical interaction, but it can provide inspiration for future projects and enable learning about new industry trends. Furthermore, online platforms are an important search space for solutions to technical problems that occur in software development. Firms can gather technological and other knowledge inputs, especially from online communities, such as internet fora and user groups (Grabher and Ibert 2018).

As a respondent from Oslo states, 'when you look at the forums from which developers get their knowledge, they are incredibly complex and very high-tech'. A respondent from Malmö highlights the role of virtual space as a source for technical knowledge, 'this [conference] is more for inspiration than to get (...) real knowledge. Basically, they are going to find the real knowledge online'. In response to the question on key sources of technical knowledge, another respondent states: 'It is the internet - it is almost only the internet. Sometimes, we go to a seminar or conference or something like that, but 99 percent is the internet.'

The results of firms' explorations in the virtual space may constitute a significant part of their knowledge input. This is because most of the software solutions they produce are composed of technologies and knowledge developed by other programmers and shared on open-source websites: 'We can use open-source solutions, which are better than the proprietary systems 99 percent of the time. Part of being in this business is that we can do everything with systems that are either free or cheap'. Consequently, the firms' competitive advantages reside in unique combinations of these knowledge pieces, and in the new meanings that knowledge and technologies gain when used in a new context. Virtual spaces focused on specific themes serve as the loci of formation of communities of practice. Participants discuss their experiences, solve 
common problems, negotiate meanings and create shared conventions (Grabher and Ibert 2014, 2018). These communities form irrespective of physical proximity. Moreover, as most activities in the virtual space are visible online (e.g., the uploading of specific content), it is possible for agents to test the coherence of others' actions, their alignment and their commitment to the same values.

It would be misleading to think that knowledge in the virtual space is instantly available at no cost (Bathelt, Malmberg, and Maskell 2004). To find inputs for innovation processes, learning is needed to understand the usefulness of each piece of knowledge and to combine them. In virtual spaces, firms can source knowledge in a unidirectional way. At the same time, they can actively contribute to knowledge generation and sharing. Firms can also act as sources, receivers and co-creators of knowledge. This became apparent in the case of open-source software (e.g., the GNU/Linux operating system and its derivative, Android), which is often generated by user communities and professional users. As pointed out by Grabher and Ibert (2018), physical proximity strengthens the social coherence within these online communities. However, even though F2F interactions may occur, they do not seem imperative, as technical knowledge is primarily sourced and exchanged in the virtual space. This does not relate solely to technical knowledge, as actors also share other content online - from research papers to complete projects. With regard to the unidirectional acquisition of knowledge, one interviewee stressed that the origins of technologies and knowledge do not matter because they are accessible to all.

The virtual space can be seen as dynamic repository of knowledge that can be accessed whenever needed. Not only is the knowledge repository continuously enlarging, but the content's meaning is also constructed and deconstructed by agents using it in their innovation efforts and interpreting it in different ways. When new content is introduced in the virtual space, even those who do not belong to the community from which it stems from can help to sharpen it further. This leads to multiple interpretations of the content based on each agent's cognitive frames (Grabher and Ibert 2014). One consequence of this echo potential is that the virtual space can be used by firms to attract the attention of different communities locally and globally: 'When we do things like this, it gets coverage in places like WIRED in Japan (...). Those things aren't rocket science (...), it's speculative work.' In this sense, an active presence in the virtual space is not only a means for sourcing knowledge. It is also a way to distribute knowledge, promote ideas, and create attention on local and global markets. 
The virtual space is also used to monitor competitors by trying to understand their innovation strategies, and their use and interpretation of technologies. This increases the risk of copying and reverse engineering, but also helps overcome technological bottlenecks and, thereby, speeds up innovation in the industry. In any case, even if information on competitors' products, strategies and networks is monitored in the virtual space, it is rarely possible to comprehend the processes used to build up relationships or to develop a technical solution. A bidirectional, trustbased relationship that goes beyond unidirectional monitoring is necessary to obtain procedural knowledge.

A final important functionality of the virtual space that has been frequently mentioned is the possibility of replicating activities that take place in the physical space. Digital-communication tools make it possible for firms to take part in conferences or meetings that happen at a geographical distance, especially when it would be too costly or time-consuming to attend these events in person.

\section{Conclusions - The Virtual and the Physical as Mutually Dependent Spaces}

The analysis highlighted the wide range of knowledge sources that firms utilize in knowledge formation. It clearly showed that the interviewed companies connected with various knowledge sources in different spaces - physical and virtual. A linkage with one source can take both physical and virtual forms, sometimes at the same time. Likewise, the virtual space is used to source knowledge both locally and globally. This variety can be explained by the need to combine different types of knowledge from different sources in order to innovate (Manniche 2012; Manniche, Moodysson, and Testa 2017; Grillitsch, Martin, and Srholec 2017).

Informal, low-cost mechanisms are undoubtedly an important input in the knowledge-formation process of software firms. These mechanisms not only take the form of informal gatherings at fairs and conferences, but also arise in virtual spaces that can have both a private and a professional nature. Much of the knowledge needed to design and build new software is available in open virtual communities, which lowers the need for the formalized contracts with suppliers and external consultants that are typical of other industries. However, as the innovation outcomes of software companies are applied to different contexts and target a variety of businesses, firms need to build and rely on networks that span various communities (similar to the advertisement industry; Grabher 2002, 2004). This network infrastructure provides firms with a continuous flow of knowledge and serves as the basis for additional entrepreneurial 
opportunities. All of these linkages, irrespective of the space in which they reside, make up the firms' knowledge and innovation spaces.

Some of the literature on innovation and knowledge sourcing has considered the virtual space as separate from the physical space, and as having fewer, purely instrumental functionalities. This subjugated role reflects a perception of the virtual space as a facilitator of the exchange of codified knowledge with limited capacity to transmit tacit knowledge (Kaufmann, Lehner, and Tödtling 2003; Bathelt and Turi 2011). In this paper, we have shown that the virtual space is not limited to the search for codified knowledge, but has several functions. It serves as an arena for interactive learning; for the exchange of technological knowledge; for sharing information through conferences, branch meet-ups and other social events; for advertising and selling new products and services; and for recruiting qualified staff. This calls for careful consideration of the virtual space in studies on innovation and knowledge formation.

We do not claim that the virtual dimension can serve as a substitute for the physical one. Instead, the virtual space should be seen as an arena that can reinforce existing knowledge linkages and allow for the establishment of new ones. With the increasing importance of the virtual space, the distinctions between geographical scales and different sources of knowledge are becoming increasingly blurred. The view of the virtual dimension as inextricably related to the physical one creates new theoretical and empirical challenges. More research is needed to understand how innovation processes and collaborative dynamics unfold at the intersection between virtual and physical spaces.

Notwithstanding these finding on the importance of physical and virtual spaces for knowledge formation, additional insights could be gained from more processual, dynamic analyses (see, e.g., Rusten and Overå 2014; Jeannerat and Crevoisier 2016). A processual perspective would not only allow for the recounting of the events that led to a certain linkage but also disclose the processual mechanisms. For example, a physical linkage in geographical proximity may lead to a new linkage to a virtual community, while attending a conference may lead to the consolidation of informal relationships and, eventually, to a formalized collaborative link. From a processual perspective, each interaction opportunity has more than one functionality or one consequence. Each knowledge linkage can serve different purposes, which might change over time. For example, a firm's participation in physical meetings, its presence in virtual communities and its engagement in R\&D collaborations may serve to enlarge and sustain networks, spread the firm's reputation and help it find partners that may help address technical problems in the innovation process. 
Additional studies could analyse the role of dormant linkages - linkages that do not actively convey knowledge but can be activated by firms as soon as they become necessary. ICT advancements allow people and firms to maintain relationships over significant geographical distances despite a lack of opportunities for physical meetings. Not only can the nature of these linkages remain intact, but ICTs have also multiplied the quantity, speed and modes of information exchange and construction (e.g., videoconferences, email, chats and dedicated blogs) with known and unknown counterparts.

Overall, we argue that in order to understand how firms access and create new knowledge for innovation, it is important to appreciate the virtual and the physical as two mutually dependent spaces. The role of the virtual space and its connection with the physical space is a promising area for new research on the geography of innovation and knowledge creation.

\section{References}

Amin, A. and P. Cohendet. 2004. Architectures of Knowledge: Firms, Capabilities, and Communities. Oxford: Oxford University Press.

Asheim, B. T. 1999. "Interactive learning and localised knowledge in globalising learning economies”. GeoJournal 49 (4): 345-352.

Asheim, B. T. and A. Isaksen. 2002. "Regional innovation systems: the integration of local “sticky" and global "ubiquitous" knowledge". Journal of Technology Transfer 27: 77-86.

Asheim, B. T. and M. S. Gertler. 2005. "The geography of innovation: regional innovation systems". In The Oxford Handbook of Innovation, edited by J. Fagerberg, D. Mowery and R. Nelson, 291-317. Oxford: Oxford University Press.

Asheim, B. T., Coenen, L. and J. Vang. 2007a. "Face-to-face, buzz, and knowledge bases: Sociospatial implications for learning, innovation, and innovation policy". Environment and Planning C: Government and Policy 25 (5): 655-670.

Asheim, B. T., Coenen, L., Moodysson, J. and J. Vang. 2007b. “Constructing knowledgebased regional advantage: Implications for regional innovation policy". International Journal of Entrepreneurship and Innovation Management 7 (2-5): 140-155. 
Aslesen, H. W. and M. Freel. 2012. "Industrial Knowledge Bases as Drivers of Open Innovation?" Industry and Innovation 19 (7): 563-584.

Bathelt, H. 2008. "Clusters and regional development: Critical reflections and explorations". Economic Geography 84 (1): 109-112.

Bathelt, H. and J. Glückler. 2003. "Towards a relational economic geography”. Journal of Economic Geography 3 (2): 117-144.

Bathelt, H., Malmberg A., and P. Maskell. 2004. "Clusters and knowledge: local buzz, global pipelines and the process of knowledge creation”. Progress in Human Geography 28 (1): 3156.

Bathelt, H. and N. Schuldt. 2008. "Between luminaires and meat grinders: international trade fairs as temporary clusters". Regional Studies 42 (6): 853-868.

Bathelt, H. and N. Schuldt. 2010. "International trade fairs and global buzz, part I: ecology of global buzz". European Planning Studies 18 (12): 1957-1974.

Bathelt, H. and P. Turi. 2011. "Local, global and virtual buzz: The importance of face-to-face contact in economic interaction and possibilities to go beyond". Geoforum 42 (5): 520-529.

Bathelt, H. and R. Gibson. 2015. "Learning in 'organized anarchies': The nature of technological search processes and knowledge flows at international trade fairs". Regional Studies 49 (6): 985-1002.

Beaudry, C., and A. Schiffauerova. 2009. "Who's right, Marshall or Jacobs? The localization versus urbanization debate". Research Policy 38 (2): 318-337.

Belk R. 2010. "Sharing". Journal of consumer research 36 (5): 715-734.

Boschma, R. A. 2005. "Proximity and innovation: A critical assessment", Regional Studies 39 (1): 61-74.

Boschma, R., Eriksson, R., and U. Lindgren. 2009. "How does labour mobility affect the performance of plants? The importance of relatedness and geographical proximity". Journal of Economic Geography 9 (2): 169-190. 
Brinks, V., Ibert, O., Müller, F. C., and S. Schmidt. 2018. "From ignorance to innovation: Serendipitous and purposeful mobility in creative processes - The cases of biotechnology, legal services and board games". Environment and Planning A: Economy and Space, $0308518 X 18758327$.

Chaminade, C., De Fuentes, C., Harirchi, G., and M. Plechero. 2017. "The Geography and Structure of Global Innovation Networks: Global Scope and Regional Embeddedness". In Handbook on the Geography of Innovation, edited by D. Doloreux, 370-381. Cheltenham: Edward Elgar.

Cohen, W. M. and D. A. Levinthal. 1990. “Absorptive Capacity: A New Perspective on Learning and Innovation”. Administrative Science Quarterly 35 (1): 128-152.

Cooke, P. 2013. "Global production networks and global innovation networks: Stability versus growth". European Planning Studies 21: 1081-1094.

Cooke, P., DeLaurentis C., Tödtling F., and M. Trippl. 2007. Regional Knowledge Economies. Cheltenham: Edward Elgar.

Ernst, D. 2009. “A new geography of knowledge in the electronics industry? Asia's role in global innovation networks". Policy studies 54, East-West Center, Honolulu.

Fai, F., Tomlinson, P. R., and J. R. Branston. 2014. "Connecting to Temporary Spaces in Far Off Places - implications for innovation in the North Staffordshire Ceramics Cluster". Paper presented at the Regional Studies Association Annual Conference 2015, Piacenza Italy, May 24-27.

Felin, T. and T. R. Zenger. 2014. "Closed or open innovation? Problem solving and the governance choice”. Research Policy 43 (5): 914-925.

Fitjar R. D. and F. Huber. 2015. "Global pipelines for innovation: insights from the case of Norway", Journal of Economic Geography 15 (3): 561-83.

Franke, N. and S. Shah. 2003. "How communities support innovative activities: an exploration of assistance and sharing among end-users". Research Policy 32: 157-178.

Friedman, T.L. 2005. The World Is Flat: A Brief History of the Twenty-first Century. New York: Farrar, Straus and Giroux. 
Gertler, M. S. 2003. "Tacit knowledge and the economic geography of context, or the undefinable tacitness of being (there)". Journal of Economic Geography 3 (1): 75-99.

Gertler M. S. and Y. M. Levitte. 2005. "Local Nodes in Global Networks: The Geography of Knowledge Flows in Biotechnology Innovation”. Industry and Innovation 12: 487-507.

Grabher G. 1993. "The weakness of strong ties; the lock-in of regional development in the Ruhr area". In The embedded firm; on the socioeconomics of industrial networks, edited by G. Grabher, 255-277. London and New York: Routledge.

Grabher G. 2002. "Cool projects, boring institutions: temporary collaboration in social context”. Regional Studies 36: 205-214.

Grabher G. 2004. "Learning in Projects, Remembering in Networks? Communality, Sociality, and Connectivity in Project Ecologies”. European Urban and Regional Studies 11 (2): 103123.

Grabher G., and O. Ibert. 2014. "Distance as asset? Knowledge collaboration in hybrid virtual communities". Journal of Economic Geography 14 (1): 97-123.

Grabher, G., and O. Ibert. 2018. "Schumpeterian Customers? How Active Users Co-Create Innovations". In The New Oxford Handbook of Economic Geography, edited by G. L. Clark, M P. Feldman, M. S. Gertler and D. Wójcik, 286-303. Oxford: Oxford University Press.

Grillitsch, M., R. Martin, and M. Srholec. 2017. "Knowledge Base Combinations and Innovation Performance in Swedish Regions". Economic Geography 93 (5): 458-79.

Hauknes, J. and M. Knell. 2009. "Embodied knowledge and sectoral linkages: An inputoutput approach to the interaction of high- and low-tech industries". Research Policy 38: 459469.

Henn, S. and H. Bathelt. 2015. "Knowledge generation and field reproduction in temporary clusters and the role of business conferences". Geoforum 58: 104-113.

Herstad, S.J., Aslesen, H.W., and B. Ebersberger. 2014. "On industrial knowledge bases, commercial opportunities and global innovation network linkages". Research Policy 43: 495504. 
Ibert, O. 2004. "Projects and firms as discordant complements: organisational learning in the Munich software ecology”. Research Policy 33 (10): 1529-1546.

Ibert, O. 2010. "Relational Distance: Sociocultural and Time-Spatial Tensions in Innovation Practices". Environment and Planning A 42 (1): 187-204.

Isaksen, A. 2004. "Knowledge-based clusters and urban location: The clustering of software consultancy in Oslo". Urban Studies 41: 1157-1174.

Isaksen A. 2006. "Knowledge-intensive industries and regional development: The case of the software industry in Norway". In Regional development in the knowledge economy, edited by P. Cooke and A. Piccaluga, 43-62. London and New York: Routledge.

Isaksen, A., and M. Trippl. 2016. "Path Development in Different Regional Innovation Systems: A Conceptual Analysis”. In Innovation Drivers and Regional Innovation Strategies, edited by M. D. Parrilli, R. D. Fitjar, and A. Rodriguez-Pose, 66-84. New York: Routledge. Jeannerat, H, and O. Crevoisier. 2016. 'Editorial: From 'Territorial Innovation Models' to "Territorial Knowledge Dynamics": On the Learning Value of a New Concept in Regional Studies”. Regional Studies 50 (2): 185-188.

Jensen, M. B., Johnson, B., Lorenz, E., and B. Å. Lundvall. 2007. "Forms of knowledge and modes of innovation". Research Policy 36 (5): 680-693.

Johnson, B., Lorenz, E., and B. Å. Lundvall. 2002. "Why all this fuss about codified and tacit knowledge?" Industrial and corporate change 11 (2): 245-262.

Jøranli, I., and Herstad, S. J. 2017. "Urban concentration and labour market linkages in the Norwegian ICT services sector”. European Planning Studies 25 (10): 1734-1755.

Kaufmann A., P. Lehner and F. Tödtling. 2003. "Effects of the Internet on the spatial structure of innovation networks". Information Economics and Policy 15 (3): 402-424.

Knoben, J. and L. A.G. Oerlemans. 2006. "Proximity and inter-organizational collaboration: a literature review". International Journal of Management Review 8: 71-89.

Leamer E. and M. Storper. 2001. "The Economic Geography of the Internet Age”. Journal of International Business Studies 32 (4): 641-665. 
Los, B., Timmer, M.P. and G.J. Vries. 2015. "How global are global value chains? a new approach to measure international fragmentation". Journal of Regional Science 55: 66-92.

Lundvall B. Å. 1992. National Innovation Systems: Towards a theory of innovation and interactive learning. London: Pinter.

Malecki, E. J. 2011. "Connecting local entrepreneurial ecosystems to global innovation networks: open innovation, double networks and knowledge integration". International Journal of Entrepreneurship and Innovation Management 14: 36-59.

Malmberg, A. and D. Power. 2005. “(How) do (firms in) clusters create knowledge?” Industry and Innovation 12: 409-31.

Manniche, J. 2012. "Combinatorial knowledge dynamics: On the usefulness of the differentiated knowledge bases model”. European Planning Studies 20 (11): 1823-1841.

Manniche, J., J. Moodysson, and S. Testa. 2017. “Combinatorial Knowledge Bases: An Integrative and Dynamic Approach to Innovation Studies”. Economic Geography 93 (5): 48099.

Markusen, A. 1996. "Sticky Places in Slippery Space: A Typology of Industrial Districts”. Economic Geography 72: 293-313.

Martin, R., and J. O. Rypestøl. 2017. "Linking content and technology: On the geography of innovation networks in the Bergen media cluster". Industry and Innovation. doi:10.1080/13662716.2017.1343132

Martin, R. and M. Trippl. 2017. "The evolution of the ICT cluster in southern Sweden regional innovation systems, knowledge bases and policy actions". Geografiska Annaler: Series B, Human Geography 99 (3): 268-83.

Maskell, P. 2014. "Accessing remote knowledge — the roles of trade fairs, pipelines, crowdsourcing and listening posts”. Journal of Economic Geography 14: 883-902.

Maskell, P., Bathelt, H. and A. Malmberg. 2004. “Temporary Clusters and Knowledge Creation: The Effects of International Trade Fairs, Conventions and Other Professional Gatherings", SPACES online, 2004-04, Marburg: Fachbereich Geographie, PhilippsUniversität Marburg. 
Maskell P., Bathelt H. and A. Malmberg. 2006. "Building global knowledge pipelines: The role of temporary clusters”. European Planning Studies 14 (8): 997-1013.

McKelvey, M., Alm, H. and M. Riccaboni. 2003. "Does co-location matter for formal knowledge collaboration in the Swedish biotechnology-pharmaceutical sector?" Research Policy 32: 483-501.

Menzel, M-P. 2015. "Interrelating Dynamic Proximities by Bridging, Reducing and Producing Distances”. Regional Studies 49 (11): 1892-907.

Merton R.K. and Barber E. 2004. The Travels and Adventures of Serendipity. A Study in Sociological Semantics and the Sociology of Science. Princeton, Oxford: Princeton University Press.

Morgan, K. 2004. "The exaggerated death of geography. Learning, proximity and territorial innovation systems". Journal of Economic Geography 4: 3-21.

Morrison A., R. Rabellotti and L. Zirulia. 2012. "When do global pipelines enhance the diffusion of knowledge in clusters?” Economic Geography 89 (1): 77- 96.

Owen-Smith J. and W. W. Powell. 2004. "Knowledge Networks as Channels and Conduits: The Effects of Spillovers in the Boston Biotechnology Community". Organization Science 15 (1): 5-21.

Parrilli, M.D., Nadvi, K. and H.W.-C. Yeung. 2013. "Local and Regional Development in Global Value Chains, Production Networks and Innovation Networks: A Comparative Review and the Challenges for Future Research". European Planning Studies 21: 967-988.

Passiante G. and G. Secundo. 2002. "From geographical innovation clusters towards virtual innovation clusters: the Innovation Virtual System". Paper presented at the ERSA Conference, Dortmund, August 27-31.

Patton, Q. M. 1990. Qualitative Evaluation and Research Methods. Newbury Park: Sage Publications.

Powell, W. W. 1998. "Learning from collaboration: Knowledge and networks in the biotechnology and pharmaceutical industries”, California Management Review 40: 228-240. 
Powell, W. W., Koput, K. and L. Smith-Doerr. 1996. "Interorganizational collaboration and the locus of innovation: Networks of learning in biotechnology". Administrative Science Quarterly 41: 116-145.

Rallet, A. and A. Torre. 1999. "Is geographical proximity necessary in the innovation networks in the era of the global economy?" GeoJournal 49: 373-380.

Roberts, J. 2000. "From Know-how to Show-how? Questioning the Role of Information and Communication Technologies in Knowledge Transfer". Technology Analysis \& Strategic Management 12 (4): 429-443.

Romano A., Passiante G. and E. Valerio. 2001. "New sources of clustering in the digital economy”, Journal of Small Business and Enterprise Development 8 (1): 19-27.

Rusten, G., and R. Overå. 2014. “Local and Global Geographies of Innovation: Structures, Processes, and Geographical Contexts from a Firm Perspective”. Growth and Change 45 (3): 403-411.

Schuldt, N. and H. Bathelt. 2011. "International trade fairs and global buzz. Part II: Practices of global buzz". European Planning Studies 19: 1-22.

Segelod E. and G. Jordan. 2004. "The use and importance of external sources of knowledge in the software development process". R\&D Management 34 (3): 239-252.

Sotarauta, M., Ramstedt-Sen, T., Kaisa Seppänen, S. and K.J. Kosonen. 2011. "Local or digital buzz, global or national pipelines: patterns of knowledge sourcing in intelligent machinery and digital content services in Finland”. European Planning Studies 19 (7): 13051330.

Storper M. and A. J. Venables. 2004. "Buzz: face-to-face contact and the urban economy". Journal of Economic Geography 4: 351-370.

Strambach, S. 2012. "Knowledge Dynamics and Knowledge Commodification of KIBS in Time and Space”. In Exploring Knowledge-Intensive Business Services, edited by E. Di Maria, R. Grandinetti and B. Di Bernardo, 56-78. Hampshire: Palgrave Macmillan. 
Tether, B. S. and A. Tajar 2008. "Beyond Industry-University Links: Sourcing Knowledge for Innovation from Consultants, Private Research Organisations and the Public Science-Base". Research Policy 37 (6-7): 1079- 1095.

Tödtling, F., Lehner, P., and M. Trippl. 2006. "Innovation in knowledge intensive industries: The nature and geography of knowledge links”. European Planning Studies 14 (8): 1035 1058.

Torre, A. and J.-P. Gilly. 2000. "On the analytical dimension of proximity dynamics", Regional Studies 34 (2): 169-180.

Trippl M. 2013. "Islands of Innovation as Magnetic Centres of Star Scientists? Empirical Evidence on Spatial Concentration and Mobility Patterns". Regional Studies 47 (2): 229-244.

Trippl, M., Tödtling, F., and L. Lengauer 2009. "Knowledge Sourcing Beyond Buzz and Pipelines: Evidence from the Vienna Software Sector”. Economic Geography 85 (4): $443-$ 462.

Trippl, M., Grillitsch, M., and A. Isaksen. 2017. "Exogenous sources of regional industrial change”. Progress in Human Geography, https://doi.org/10.1177/0309132517700982.

Vaccaro A., F. Veloso and S. Brusoni. 2009. "The impact of virtual technologies on knowledge-based processes: An empirical study”. Research Policy 38 (8): 1278-1287.

Yeung, H. W. C. 2005. "Rethinking relational economic geography”. Transactions of the Institute of British Geographers 30: 37-51.

Zahra, S. and G. George. 2002. "Absorptive capacity: A review, reconceptualization, and extension”. Academy of Management Review 27 (2): 185-203. 